\title{
PENGARUH PROMOSI JABATAN TERHADAP PRESTASI KERJA PEGAWAI PADA KANTOR BADAN PENGAWAS DAERAH KABUPATEN TULANG BAWANG
}

\author{
Oleh: \\ Suhartina ${ }^{1}$ \\ Yusuf Riyadi $^{2}$ \\ Program Studi Administrasi Bisnis, Universitas Tulang Bawang Lampung \\ e-Mail: suhartina@utb.ac.id
}

\begin{abstract}
ABSTRAK
Promosi jabatan adalah kesempatan yang diberikan kepada pegawai untuk maju danberkembang sehingga dapat mendorong pegawai untuk lebih baik atau meningkatkansemangat kerja di lingkungan organisasi atau perusahaan tempatnya bekerja. Pimpinan organisasi perlu menyadari pentingnya promosi jabatan dalam meningkatkan produktivitas organisasi yang harus dipertimbangkan seeara obyektif. Keputusan promosi terhadap jabatan yang dilaksanakan harus meneerminkan keadilan bagi semua pihak. Dengan demikian penilaian terhadap prestasi kerjapegawai yang teiah diberikan oleh seorang pimpinan adalah benar-benar obyektif. Pada Kantor Badan Pengawas Daerah Kabupaten Tulang Bawang yang merupakansalah satu elemen dari sistem pengawasan penyelenggaraan pemerintahan, pelaksanaan penilaian prestasi kerja pegawai mengaeu pada standar penilaian DP3 dengan berdasarkan pada Surat Edaran Gubernur Lampung Nomor 800/2540/08/1998 tanggal 22 Desember 1998 dengan berpedoman pada Peraturan Pemerintah Nomor 10Tahun 1979.
\end{abstract}

Adapun masalah pokok dalam pelaksanaan promosi jabatan terhadap prestasi kerjapegawai pada Kantor Badan Pengawas Daerah Kabupaten Tulang Bawang adalah "apakah pelaksanaan promosi jabatan berpengaruh terhadap prestasi kerja pegawai pada Kantor Badan Pengawas Daerah Kabupaten Tulang Bawang". Berdasarkan masalah pokok tersebut, maka tujuan penelitian yang dilakukan adalah sebagai berikut: Untuk mengetahui bagaimana pelaksanaan promosi jabatan yang diterapkan pada Kantor Badan Pengawas Daerah Kabupaten Tulang Bawang, Untuk mengetahui pengaruh dari promosi jabatan terhadap prestasi kerja pegawai pada Kantor Badan Pengawas Daerah Kabupaten Tulang Bawang. Kegunaan penelitian ini adalah diharapkan hasil penelitian ini sebagai sumbangan pemikiran dan saran bagi Kantor Badan Pengawas Daerah Kabupaten Tulang Bawang. Hasil Penelitian: Promosi jabatan tidak berpengaruh terhadap prestasi kerja pegawai pada Kantor Badan Pengawas Daerah Kabupaten Tulang Bawang

Promosi jabatan berpengaruh terhadap prestati kerja pegawai pada Kantor Badan Pengawas Daerah Kabupaten Tulang Bawang.

Adapun metode penelitian yang digunakan adalah penelitian kualitatif yang menggambarkan keadaan di lapangan berdasarkan kenyataan yang ada yang ditunjang dengan teori dan literatur yang mendukung dan penelitian kuantitatif yaitu penelitian berdasarkan angka-angka yang didapatkan dari hasil penyebaran angket atan kuisioner yang kemudian diolah menggunakan uji statistik.Dalam penelitian ini yang dijadikan responden adalah keseluruhan dari populasi yakni 
sebanyak 29 orang, sehingga penelitian penulis bersifat penelitian populasi Teknik sampling yang dipakai adalah stratified random samplin. Proses analisis merupakan usaha untuk menemukan jawaban atas pertanyaan tentang Permasalahan yang dirumuskan dan diperoleh selama penehtian Adapan metodeAnalisis data yang akan digunakan adalah analisis kuantitatif dan analisis kualitatif. Dari perhitungan dengan menggunakan uji statistik produet moment, diketahui $r_{\text {hitung }}=0,740$ Hasil tersebut jika dikonsultasikan dengan nilai $r_{\text {tabel }}$ dengan $\mathrm{N}=29$ pada taraf signifikansi $1 \%=0,470$ dan taraf signifikansi 5\%=0367 Hasil konsultasi ternyata $\mathrm{r}_{\text {hitung }}$ lebih besar daripada $\mathrm{r}_{\text {tabel. }}$. Dengan demikian hipotesis: $\mathrm{H}_{1}$ : Promosi jabatan berpengaruh terhadap prestasi kerja pegawai pada Kantor Badan Pengawas Daerah Kabupaten Tulang Bawang diterima.

Untuk mengetahui tingkat ke-eratan pengaruh promosi jahatan terhadap prestasi kerja pegawai pada kantor Badan Pengawas Daerah Kabupaten Tulang Bawang, maka hasil perhitungan $\left(\mathrm{r}_{\text {hitung }}\right)=0,740$ akan dikonsultasikan dengan tabel nilai standar korelasi Setelah dikonsultasikan ternyata nilai 0,740 termasuk dalam standar nilai antara 0,600-0,800 dengan kategori interprestasi "berpengaruh tinggi"

Kata Kunci: promosi jabatan, prestasi kerja pegawai

\section{PENDAHULUAN}

\section{A. Latar Belakang}

Organisasi selain sebagai wadah ataupun alat untuk mencapai tujuan juga merupakan bentuk dari suatu kerjasama antara sekelompok orang guna meneapai tujuan bersama berdasarkan aturan dan prinsip-prinsip tertentu Aturan-aturan dan prinsip-prinsip yang harus ditaati tidak hanya berbentuk tata tertib, tata krama atau aturan dan prinsip yang berkaitan dengan etika, akan tetapi menyangkut aturan-aturan dan prinsip-prinip yang berkaitan langsung dengan tugas dan tanggung jawab pegawai sebagai pelaksana dari pembangunan itu. Dalam perkembangan aktifitas organisasi, faktor sumber daya manusia memiliki posisi terpenting dan menentukan dalam peneapaian tujuan organisasi. Oleh karena itu penanganan sumber daya maninia menjadi prioritas utama dan penanganannya perlu memperhatikan berbagai hal yang dapat mempengaruhi pelaksanaan tugas dan tanggung jawabnya agar tujuan organisasi dapat tereapai dengan efektif dan efisien Sumber daya manusia di suatu unit organisasi perlu dikelola seeara profesional agar terwujud keseimbangan antara kebutuhan pegawai dengan tuntutan dan kemampuan organisasi Keseimbangan tersebut merupakan kunei utama organisasi agar dapat berkembang seeara produktif dan wajar. Hal ini juga ditentukan oleh peranan Pimpinan dalam memberikan motivasi atau dorongan kepada pegawainya sehingga dapat tereipta semangat kerja dari pegawai. Salah satu bentuk motivasi atau dorongan yang dapat diberikan pimpinan kepada bawahan atau pegawainya adalah dengan eara memberikan promosi jabatan kepada pegawainya.

Promosi jabatan adalah kesempatan yang diberikan kepada pegawai untuk maju dan berkembang sehingga dapat mendorong pegawai untuk lebih baik atau meningkatkan semangat kerja di lingkungan organisasi atau perusahaan tempatnya bekerja. Pimpinan organisasi perlu menyadari pentingnya promosi jabatan dalam meningkatkan produktivitas organisasi yang harus dipertimbangkan seeara obyektif. Dengan adanya promosi, 
pegawai akan merasa dirinya diperhatikan, dibutuhkan dan diakui oleh pimpinan organisasi. Promosi jabatan yang diberikan kepada pegawai dapat meningkatkan prestasi kerja pegawai sehingga menghasilkan produktivitas kerja pegawai yang tinggi serta akan membuat pegawai loyal (setia) pada organisasi tempatnya bekerja. Tidak semua pegawai yang berprestasi dapat seeara langsung dipromosikan. Hal ini mengingat formasi jabatan yang tersedia di dalam suatu struktur organisasi yang terbatas. Keputusan promosi terhadap jabatan yang diambil harus meneerminkan keadilan bagi semua pihak. Dengan demikian penilaian yang telah diberikan oleh seorang pimpinan adalah benar-benar obyektif.

Seperti halnya pada Kantor Badan Pengawas Daerah Kabupaten Tulang Bawang yang merupakan salah satu elemen dari sistem pengawasan penyelenggaraan pemerintahan, pelaksanaan penilaian prestasi kerja pegawai mengaeu pada standar penilaian DP3 dengan berdasarkan pada Surat Edaran Gubernur Lampung Nomor 800/2540/08/1998 tanggal 22 Desember 1998 dengan berpedoman pada Peraturan Pemerintah Nomor 10 Tahun 1979. Penilaian terhadap prestasi kerja pegawai tersebut dimaksudkan untuk menunjang syarat dan ketentuan dalam melasanakan promosi jabatan.

Pada Kantor Badan Pengawas Daerah Kabupaten Tulang Bawang, dapat diketahui bahwa tingkat prestasi kerja pegawai masih rendah terlihat dari masih adanya pegawai yang sering terlambat masuk kerja serta adanya pegawai yang absen namun tidak mendapat teguran atau peringatan dari pimpinan. Hal tersebut mempengaruhi hasil kerja serta produktivitas kerja pegawai yang pada akhirnya banyak pekerjaan yang tidak dapat dilaksanakan seeara efektif dan efisien. Prestasi kerja pegawai yang masih rendah tersebut juga dipengaruhi oleh faktor lain, seperti kurangnya perhatian serta belum bersikap adilnya pimpinan atau Kepala Badan terhadap pegawai atau bawahannya dalam pelaksanaan pekerjaan maupun dalam memberikan tugas-tugas kantor, serta profesionalisme sumber daya manusia belum merata sedangkan bidang tugas pengawasan eukup dinamis terutama dalamSituasi otonomi daerah sekarang ini.

Rendahnya prestasi kerja pegawai pada Kantor Badan Pengawas Daerah KabupatenTulang Bawang diiringi juga dengan sedikitnya formasi untuk promosi jabatan yang tersedia. Ini disebabkan karena masih belum berjalan seeara maksimalnya organisasiPada kantor Badan Pengawas Daerah Kabupaten Tulang Bawang. Sehubungan dengan uraian-uraian di atas, penulis merasa tertarik dan terdorong untukMelakukan penelitian untuk pembuatan skripsi yang berjudul : Pengaruh Promosi Jabatan Terhadap Prestasi Kerja Pegawai pada Kantor Badan Pengawas Daerah Kabupaten Tulang Bawang,

\section{Tujuan dan Kegunaan Penelitian}

1. Tujuan Penelitian

$\begin{array}{llr}\text { a. } & \text { Untuk mengetahui } \\ \text { bagaimana pelaksanaan } \\ \text { promosi jabatan yang } \\ \text { diterapkan pada } & \text { Kantor } \\ \text { Badan Pengawas Daerah } & \text { Tulang } \\ \text { Kabupaten } & \\ \text { Bawang. } & \\ \text { b. Untuk mengetahui } \\ \text { pengaruh dari promosi } \\ \text { jabatan terhadap prestasi } \\ \text { kerja pegawai pada Kantor } \\ \text { Badan Pengawas Daerah } \\ \text { Kabupaten } \\ \text { TulangBawang.l }\end{array}$

\section{Kegunaan Penelitian}


a. Diharapkan hasil penelitian ini sebagai sumbangan pemikiran dan saran bagi Kantor Badan Pengawas Daerah Kabupaten Tulang Bawang atau yang memerlukan.

b. Sebagai syarat akademik dalam meneapai Gelar Sarjana $\quad\left(\mathrm{S}_{1}\right) \quad$ Ilmu Administrasi Negara pada Fakultas Ilmu Sosial dan Ilmu Politik Universitas Tulang Bawang (UTB) Lampung.

\section{Kajian Pustaka}

\subsection{Pengertian Promosi Jabatan}

Promosi berarti kenaikan jabatan yaitu menerima kekuasaan dan tanggung jawab yang lebih besar dari kekuasaan dan tanggung jawab sebelumnya. Pemberian Promosi kepada seseorang pegawai berarti bahwa pegawai tersebut mempunyai kesempatan naik ke posisi yang lebih tinggi dalam struktur organisasi. Promosi jabatan merupakan kebijakan dari seorang pimpinan untuk memotivasi pegawai dalam mengembangkan diri sehingga dapat berprestasi dan tereiptanya prestasi yang tinggi,dimana akan berpengaruh terhadap peneapaian tujuan organisasi seeara efektif dan efisien. Kebijakan promosi selain untuk memenuhi kebutuhan pegawai juga untuk memenuhi kebutuhan organisasi.

Drs. Moekijat (1995:145) mengatakan promosi jabatan adalah kemajuan dari seorang pegawai pada suatu tugas yang lebih baik dipandang dari sudut tanggung jawab yang lebih besar, status lebih tinggi, keeakapan yang lebih besar terutama pembayarantambahan upah atau gaji.

Menurut M. Manullang (1992:107), promosi jabatan adalah kenaikan jabatan yakni menerima kekuasaan dan tanggung jawab yang lebih tinggi dari tanggung jawab sebelumnya.

Sedangkan menurut Drs. Heidjrahman dan Drs. Suad Husnan, MBA (1992:111) promosi jabatan adalah perpindahan dari suatu jabatan ke jabatan yang lain yang mempunyai status, tanggung jawab yang lebih tinggi dan disertai dengan peningkatan gaji atau upah dan hak-hak lainnya.

Berdasarkan uraian beberapa pengertian promosi jabatan di atas, dapat disimpulkan bahwa promosi jabatan merupakan kenaikan kedudukan yang diikuti dengan menerima kekuasaan dan tanggung jawab yang lebih tinggi, status yang lebih tinggi, keeakapan yang lebih tinggi, gaji dan hak-hak lain yang lebih tinggi dalam suatu organisasi.

\subsection{Pengertian Prestasi Kerja}

Pada dasarnya manusia itu pada prinsipnya ingin maju dan berprestasi, apabila bekerja pada tempat dan lingkungan yang menyenangkan dan suasana kerja yang demokratis dengan gaya pengelolaan yang partisipasif, ia akan rela menerima dan bertanggung jawab. Oleh karena itu merupakan tugas dan tanggung jawab setiap unsur pimpinan dari setiap organisasi untuk menumbuhkan iklim kerja yang sehat, sehingga semua anggota organisasi mempunyai kesempatan untuk menumbuhkan daya kreatifitas yang terdapat dalam dirinya. Karena dengan keadaan demikian akan menumbuhkan dan meningkatkan efisiensi, efektifitas dan produktifitas organisasi, bahkan akan mempermudah pimpinan organisasi untuk mengarahkan prilaku para bawahannya akan dapat lebih berprestasi.

Menurut Drs. Moekijat (1992:213) bahwa tingkat kebutuhan manusia yang tertinggi 
adalah prestasi. Hubungannya antara motivasi dengan prestasi seseorang merupakan hubungan yang sangat penting, ia mengatakan orang yang berprestasi adalah orang orang yang berhasil dalam berorganisasi, mereka adalah individuindividu yang memeeahkan masalahmasalah dan meneapai tujuan organisasi, dalam prakteknya mereka adalah orangorang yang mengerjakan dan meneapai hasil-hasil yang diinginkan oleh pimpinan organisasi.

Menurut Prof. Dr. SP. Siagian, MPA, (1994:14) agar bawahan dapat berprestasi, seseorang pimpinan harus berpedoman kepada faktor-faktor dibidang :

1. Orang akan lebih giat bekerja bila kondisi sosial dalam organisasi memuaskan, Dan orang yang berpendidikan rendah kurang dapat bekerja dengan baik di Tengahtengah orang yang berpendidikan tinggi, demikian pula sebaliknya.

2. Orang akan lebih giat bekerja dalam organisasi dimana terdapat hubungan kerja sama dan saling pengertian yang baik antara pekerja dalam melaksanakan tugas.

3. Orang akan lebih giat bekerja manakala jalinan prosedur, metode yang digunakan dalam organisasi sudah eukup jelas.

4. Orang akan lebih giat bekerja dalam suatu organisasi dimana hubungan pribadi antara anggotaanggotanya terjalin kuat didasarkan rasa persahabatan dan solidaritas yang baik.

Selanjutnya menurut pendapat Drs. Moekijat (1997:215), kemudian pimpinan harus memperhatikan beberapa langkah untuk mengembangkan prestasi kerja bahwa:
1. Tujuan hasil akhir dari kegiatan harus jelas.

2. Tujuan yang ingin dieapai harus menunjukan tingkat resiko pada individu yang Terlibat.

3. Tujuan harus mempunyai sifat sehingga dapat disesuaikan sebagai jaminanSituasi, bila tujuan itu banyak berbeda.

4. Individu harus diberi umpan balik yang seksama dan jujur mengenai prestasi kerja.

5. Individu harus diberi tanggung jawab terhadap hasil kegiatan mereka.

6. Penghargaan dan hukuman yang berhubungan dengan hasil kerja yang berhasilAtau gagal harus dapat dilaksanakan dengan mestinya

Jadi yang dimaksud dengan Prestasi Kerja adalah hasil kerja yang dieapai oleh seseorang. Prestasi Kerja erat hubungannya dengan produktivitas para pegawai. Produktivitas kerja pegawai akan mendukung berhasil atau tidaknya suatu organisasiDalam usaha meneapai tujuan.

Menurut Hani Handoko (1995-99) Penilaian prestasi kerja adalah proses melalui organisasi-organisasi menilai prestasi pegawai.

Apabila penilaian prestasi kerja tersebut dilaksanakan dengan baik, tertib dan benar, dapat membantu meningkatkan motivasi kerja dan sekaligus juga meningkatkan loyalitas organisasi dari para pegawai. Hal ini tentunya akan menguntungkan organisasi yang bersangkutan sendiri. Paling tidak pegawai akan mengetahui sampai dimana dan bagaimana prestasi kerjanya dinilai oleh atasan atau tim penilai. Kelebihan maupun kekurangan yang ada dan dapat merupakan eambuk kemajuan kemajuan mereka 
mendatang. Penilaian prestasi kerja pegawai pada dasarnya merupakan penilaian yang sistematik terhadap penampilan kerja pegawai itu sendiri dan terhadap taraf potensi pegawai dalam upaya mengembangkan diri untuk kepentingan organisasi.

Dalam penilaian prestasi kerja pegawai dengan demikian sasaran yang menjadi objek penilaian antara lain adalah keeakapan dan kemampuan melaksanakan tugas yang diberikan, penampilan dalam melaksanakan tugas, eara membuat atas pelaksanaan tugas, ketenangan jasmani dan rohaninya selama bekerja dan sebagainya. Tentunya penilaian prestasi yang tinggi, senantiasa akan diberikan kepada pegawai yang memiliki dedikasi yang baik, berinisiatif positif sehat jasmani dan rohani, mempunyai Semangat berkerja dan mengembangkan diri dalam pelaksanaan tugas, pandai bergaul dan sebagainya.

\subsection{Hubungan Antara Promosi Jabatan dengan Prestasi \\ Kerja Pegawai}

Salah satu bentuk perangsang bagi pegawai yang berupa non materi dalam rangka usaha meningkatkan prestasi kerja pegawai sangat erat atau sangat dipengaruhi oleh perhatian seorang pimpinan terhadap pegawai tersebut. Perhatian dari seorang pimpinan salah satunya dapat diimplementasikan dalam hal promosi jabatan. Dengan adanya promosi jabatantersebut akan menimbulkan ambisi pegawai untuk meningkatkan produktivitas, kemampuan, kemauan, serta disiplin kerja. Drs. Winardi (1992:23) mengemukakan pendapat yaitu seorang pimpinan yang sedang bergerak ke atas dalam tangga hirarki dapat menarik pekerja baik, tetapi bilamana ia sudah mencapai puncak tangga tersebut, maka ia akan kehilangan andai kata ia bukan tipe pimpinan yang serba bisa (all around). Bilamana pimpinan tersebut tidak mempunyai perhatian terhadap bawahannya dan hampir berusaha tidak mengembangkan mereka, dan bilamana ia seorang yang tidak sportif atau berprasangka dalam hal memperlakukan mereka, maka sudah dapat dipastikan bahwa ia tidak dapat mengharapkan adanya loyalitas dari mereka.

Dari pendapat di atas nampak bahwa setiap pimpinan dalam suatu organisasi atau instansi baik itu instansi pemerintah maupun swasta bertanggungjawab untuk memajukan serta mengembangkan prestasi kerja pegawainya. Salah satu jalan untuk mengembangkan prestasi kerja pegawai ini adalah dengan jalan memberikan kesempatan serta fasilitas, mempromosikan serta kalau perlu mengalih tugaskan. Usaha meningkatkan prestasi kerja pegawai adalah merupakan suatu usaha dari seorang pimpinan yang mempunyai maksud meningkatkan serta menambah keahlian dan efisiensi kerja para bawahannya didalam melaksanakan tugas dan menempatkan mereka pada jabatan yang sesuai dengan keahlian yang dimiliki oleh pegawai tersebut. Pendapat tersebut di atas selain menjelaskan bahwa promosi jabatan dan prestasi kerja itu juga menjadi tanggung jawab seorang pimpinan, juga dari pendapat itu dapat dilihat hubungan yang erat antara peningkatan jabatan dengan prestasi kerja pegawai terhadap adanya promosi jabatan, sebab usaha pengembangan dan juga prestasi kerja pegawai itu dapat dieapai melalui promosi jabatan.

\section{METODOLOGI PENELITIAN}

\subsection{Gambaran Umum Tempat Penelitian}

Penyelenggaraan pemerintahan di kabupaten/kota dapat dilaksanakan dengan 
baik apabila penyelenggaraannya mendapat pengawasan fungsional internal. Salah satu badan yang melaksanakan pengawasan fungsional internal terhadap penyelenggaraan pemerintahan kabupaten/kota adalah Badan Pengawas Daerah. Seperti halnya Badan Pengawas Daerah Kabupaten Tulang Bawang yang terbentuk berdasarkan Perda Nomor 3 Tahun 2001 tentang pembentukan organisasi dinas dan badan dan dituangkan lebih lanjut dalam Keputusan Bupati Tulang Bawang Nomor 15 Tahun 2001 yang disempurnakan dengan dituangkan dalam peraturan daerah Kabupaten Tulang Bawang Nomor 07 Tahun 2003 tentang Pembentukan Organisasi dan Tata Kerja Lembaga Teknis Daerah Kabupaten Tulang Bawang dan Keputusan Bupati Tulang Bawang Nomor 21 Tahun 2003 tanggal 16 Desember 2003 tentang Penjabaran Tugas Pokok dan Fungsi Badan Pengawas Daerah Kabupaten Tulang Bawang.

Sebagai salah satu elemen dari sistem pengawasan penyelenggaraan pemerintahan,Pengawasan fungsional internal pemerintah akan berhasil seeara optimal apabila dilaksanakan seeara terpadu dan bersinergi dengan baik dengan elemen sistem pengawasan penyelenggaraan pemerintahan lainnya yaitu pengawasan fungsional ekstern pemerintah, pengawasan masyarakat, dan pengawasan legislatif. Peran Badan Pengawas Daerah Kabupaten Tulang Bawang sebagai pengawas internal dapat dikategorikan sebagai watedog, evaluator, dan katalisator harus mampu merespon terhadap berbagai perubahan yang terjadi dalam penyelenggaraan pemerintahan untuk memenuhi tuntutan terselenggaranya good governanee. Tugas yang harus dilaksanakan Badan Pengawas Daerah Kabupaten Tulang Bawang adalah membantu Bupati dalam memimpin, mengkoordinasikan, mengawasi dan mengendalikan semua kegiatan Badan di bidang pengawasan. Untuk menyelenggarakan tugas tersebut, Badan Pengawas Kabupaten Tulang Bawang mempunyai fungsi sebagai berikut:

a. Penyelenggaraan pereneanaan dan perumusan kebijakan pelaksanaan di bidang pengawasan.

b. Penyusunan dan penetapan program kerja dalam rangka pelaksanaan tugas.

c. Pemberian informasi, saran dan pertimbangan di bidang pengawasan kepada Bupati sebagai bahan untuk menetapkan kebijaksanaan atau membuat keputusan.

d. Penyelenggaraan koordinasi dan hubungan kerjasama dengan semua instansi,Untuk kepentingan pelaksanaan tugas.

e. Pelaksanaan kebijaksanaan di bidang pengawasan yang ditetapkan oleh Bupati.

f. Pelaksanaan tugas lain yang diberikan oleh Bupati.

Sebagai panduan pencapaian hasil yang optimal dalam penyelenggaraan tugas pokok dan fungsinya, ditetapkan visi Badan Pengawas Daerah Kabupaten Tulang Bawang,Yaitu:

"Pengawasan yang efektif, profesional, dan bertanggung jawab “

Sedangkan untuk meneapai visi tersebut, Badan Pengawas Daerah Kabupaten TulangBawang mengemban misi sebagai berikut:

1. Mendukung terwujudnya pemerintah yang akuntabel.

2. MendukungOptimalisasiPotensiPen erimaanNegara/Daerah dalam pembangunan. 
3. Mewujudkan efektifitas dan efisiensi penggunaan keuangan Negara/Daerah.

4. Mendukung tereiptanya pemerintahan yang bersih.

5. Meningkatkan sumber daya pengawasan yang profesional.

Dalam meneapai visi dan misi tersebut, dibutuhkan sumber daya manusia yang memiliki kemampuan sesuai dengan bidangnya. Sumber daya manusia atau Pegawai Negeri Sipil di lingkungan Badan Pengawas Daerah Kabupaten Tulang Bawang pada tahun 2008 adalah berjumlah 29 orang dengan rineian sebagai berikut:

Tabel 1. Keadaan Pegawai pada Kantor Badan Pengawas Daerah Kabupaten Tilsng Bawang 2008

\begin{tabular}{|c|l|c|}
\hline No. & Pangkat/Golongan & Jumlah \\
\hline 1 & Golongan IV & 5 orang \\
\hline 2 & Golongan III & 14 orang \\
\hline 3 & Golongan II & 10 orang \\
\hline 4 & Golongan I & -orang \\
\hline & Jumlah 29 orang \\
\hline & Sumber : Bawasda Tulang \\
\hline
\end{tabular}

Bawang, 2008

Adapun Pegawai Negeri Sipil dalam jabatan struktural dilingkungan Badan Pengawas Daerah Kabupaten Tulang Bawang pada tahun 2008 berjumlah 13 orang dengan rineian sebagai berikut :

Tabel 2. Keadaan Pegawai Dalam Jabatan Struktural pada Kantor Badan Pengawas Daerah Kabupaten Tulang Bawang Tahun 2008

\begin{tabular}{|c|l|c|}
\hline No & Jabatan Struktural & Jumlah \\
\hline 1 & Eselon II & 1 orang \\
\hline 2 & Eselon III & 4 orang \\
\hline 3 & Eselon IV & 8 orang \\
\hline & Jumlah & 13 orang \\
\hline \multicolumn{2}{|c|}{ Sumber : Bawasda Tulang } \\
Bawang, 2008
\end{tabular}

\subsection{Metode Penelitian}

1. Tipe Penelitian

Tipe penelitian ini adalah penelitian kualitatif dan penelitian kuantitatif. Penelitian kualitatif yang menggambarkan keadaan di lapangan berdasarkan kenyataan yang ada yang ditunjang dengan teori dan literatur yang mendukung, sedangkan penelitian kuantitatif yaitu penelitian berdasarkan angka-angka yang didapatkan dari hasil penyebaran angket atau kuisioner yang kemudian diolah menggunakan uji statistik. Adapun yang menjadi objek dalam pembahasan penelitian ini adalah pegawaiPada Kantor Badan Pengawas Daerah Kabupaten Tulang Bawang.

\subsection{Metode Penelitian}

Metode penelitian yang penulis lakukan adalah metode survey atau penelitian Lapangan yaitu mengadakan penelitian langsung ke objek penelitian untuk memperoleh data sesuai dengan pembahasan penelitian.

\subsection{Ruang Lingkup Penelitian}

Penelitian ini penulis laksanakan di Kantor Badan Pengawas Daerah KabupatenTulang Bawang.

\subsection{Metode Analisis}

Metode analisis yang dipergunakan dalam pembahasan penelitian ini adalah metode kuantitatif, dikarenakan data yang dikumpulkan merupakan data kuantitatif atau data yang berupa angka-angka yang didapatkan dari hasil penyebaran angket (kuisioner) kepada responden penelitian.

\section{Teknik Pengumpulan Data}

Untuk mengumpulkan data, penulis menggunakan teknik sebagai berikut:

a. Penelitian perpustakaan 
Yaitu mempelajari dan menyelidiki serta mengutip seeara langsung literatur yang mendukung dalam penulisan skripsi ini.

b. Penelitian lapangan

Yaitu pengumpulan data atau informasi dengan eara mengambil langsung pada

Objek penelitian dengan harapan dapat memperoleh data dan informasi yang empiris.

c. Survei

Yaitu mengumpulkan data dengan mengadakan pengamatan seeara langsungTerhadap obyek yang akan diteliti.Ini merupakan teknik bantu yang digunakan untuk memperoleh data mengenaiObyek penelitian.

d. Interview

Adalah mengumpulkan data dengan mengadakan tanya jawab pada pegawai sebagai responden yang dijadikan sampel penelitian, juga terhadap para pegawai yang dianggap mengerti permasalahan yang sedang dihadapi.

e. Kuisioner

Merupakan teknik pokok yang digunakan untuk mengungkap datadata tentang pengaruh promosi jabatan terhadap prestasi kerja pegawai yang sedang diselidiki dengan menggunakan daftar pertanyaan yang harus dijawab oleh responden yang menjadi obyek dalam penelitian ini.

f. Dokumentasi

Merupakan sumber informasi berupa bahan-bahan tertulis pada Kantor BadanPengawas Daerah Kabupaten Tulang Bawang.

\section{Teknik Pengolahan Data}

Pengolahan data yang digunakan dalam penelitian ini adalah: a. Data Primer

Yaitu data yang dikumpulkan dan diolah sendiri oleh suatu organisasi atau perorangan langsung pada obyek pokoknya.

Dalam usaha untuk mengumpulkan data primer penulis mengambil beberapa pegawai sebagai responden dan untuk memperoleh data tersebut dipergunakan metode kuisioner dan interview.

b. Data sekunder

Yaitu data yang diperoleh dalam bentuk yang sudah jadi, sudah dikumpulkan dan diolah pihak lain, biasanya telah dalam bentuk publikasi. Data sekunder diperlukan yaitu tentang Kantor Badan Pengawas Daerah Kabupaten TulangBawang.

\section{Teknik Analisis Data}

Proses analisis merupakan usaha untuk menemukan jawaban atas pertanyaan tentang permasalahan yang dirumuskan dan diperoleh selama penelitian. Adapun metode analisis data yang akan digunakan adalal1:

a. Analisis kuantitatif

Yaitu metode pengolahan data yang berupa angka-angka yang diperoleh agar lebih berdaya guna sehingga nantinya dapat ditarik suatu kesimpulan. Adapun untuk mengetahui korelasi dari dua variabel yaitu variabel bebas dan variabel terikat, penulis menggunakan rumus produet moment dengan formulasi sebagai berikut:

$$
\begin{gathered}
r x y=\frac{n \cdot \sum x y-\left(\sum x\right)\left(\sum v\right)}{\sqrt{ }\left[n 2 x^{2}-(2 x)\right][} \\
\left.E y^{2}-(E x)^{2}\right]
\end{gathered}
$$

Keterangan:

rxy : Koefisien korelasi 
$\Sigma \chi \quad:$ Skor variabel bebas

$\Sigma y \quad:$ Skor variabel terikat

n : Jumlah responden

$\sum \mathrm{x}^{2}$ : Hasil perkalian kuadrat skor dan variabel bebas

$\sum y^{2}$ : Hasil perkalian kuadrat skor angket dan variabel

terikat.

(Sutrisno Hadi, 1999:19)

Sebelum dimasukkan ke dalam rumus, maka hasil angket yang terkumpul dari responden, penulis berikan perubahan dimana ketentuan perubahan adalah sebagai berikut:

1. Setiap alternatif jawaban yang diberikan mempunyai skor:

a. Alternatif jawaban a diberi nilai 3

b. Alternatif jawaban b diberi nilai 2

c. Alternatif jawaban e diberi nilai 1

Dari pengertian diatas penulis akan tabulasikan dalam skor hasil jawaban responden variabel y dan variabel $\mathrm{x}$ dengan jalan menganalisa dan menjumlahSkor variabel $\mathrm{x}$ dan variabel y.

2. Menjumlahkan skor variabel $\mathrm{x}$ dan variabel y.

3. Memasukkan nilai skor yang disalurkan ke dalam tabel kerja korelasi dengan menganalisanya menggunakan rumus produet moment. Sedangkan untuk mengerahui keeratan pengaruh dua variabel adalah sebagai berikut:

- $\quad 0,800-1,000=$ Sangat tinggi

- $\quad 0,600-0,800=$ Tinggi

- $\quad 0,400-0,600=$ Sedang

- $\quad 0,200-0,400=$ Rendah

- $0,000-0,200=$ Sangat rendah

( Sutrisno Hadi, 2001:275)
Selanjutnya penulis menggunakan rumus koefisien penentu (KP) untuk mengetahui bagaimana pengaruh promosi jabatan terhadap prestasi kerja pegawai

$$
K p=r^{2} x 100 \%
$$

Keterangan:

$\mathrm{Kp}=$ Koefisien penentu

$\mathrm{r}^{2} \quad=\mathrm{r}$ hitung

Sedangkan untuk menguji signifikan atau tidaknya penulis menggunakan rumusSebagai berikut:

$$
t=\underline{(r)(n-2)}
$$

$$
1-r
$$

Keterangan:

$t \quad=$ Penguji koefisien korelasi

$r \quad=$ Koefisien korelasi

$n \quad=$ Jumlah responden

b. Analisis Kualitatif

Adalah suatu analisa dengan menggunakan uraian penjelasan dengan eara membandingkan teori dan pelaksanaan atau praktek pada Kantor Badan PengawasDaerah Kabupaten Tulang Bawang.

\section{ANALISIS DATA}

\subsection{Analisis Kuantitatif}

Analisis kuantitatif ini penulis gunakan agar hasil penelitian ini benar-benar ilmiah dan dapat dipertanggungjawabkan yang didasari oleh hasil perhitungan-perhitungan seeara uji statistik sehingga dapat diketahui pengaruh promosi jabatan terhadap prestasi kerja pegawai pada Kantor Badan Pengawas Daerah Kabupaten Tulang Bawang, dimana seperti telah dikemukakan pada Bab III untuk analisisnya penulis menggunakan uji statistik korelasi produet moment, yaitu sebagai berikut: 


$$
R x y=\quad \begin{gathered}
\frac{n \cdot \Sigma x y-(\Sigma \chi)(\Sigma v)}{\sqrt{ }\left[n \cdot \Sigma x^{2}-(2 x)^{2}\right]\left[n \cdot \Sigma y^{2}-\right.} \\
\left.(2 y)^{2}\right]
\end{gathered}
$$

Setelah diketahui korelasi dari perhitungan tersebut diatas, kemudian dipergunakan eara pengujian signifikasi dengan tabel $r$, yang dapat disimpulkan sebagai berikut:

- Apabila hasil perhitungan $r$ hitung lebih besar dari $r$ tabel, baik pada taraf signifikan 5\% maupun pada taraf $1 \%$, maka kesimpulannya adalah ada pengaruh yang signifikan antara promosi jabatan terhadap prestasi kerja pegawai pada Kantor Badan Pengawas Daerah Kabupaten Tulang Bawang.

- Apabila hasil perhitungan $r$ hitung lebih keeil dari $r$ tabel, baik pada taraf signifikan 5\% maupun taraf signifikan $\quad 1 \%, \quad$ maka kesimpulannya adalah tidak ada pengaruh yang signifikan antara promosi jabatan terhadap prestasi kerja pegawai pada Kantor Badan Pengawas Daerah Kabupaten Tulang Bawang. (Sutrisno Hadi, 1991:64)

Untuk mengoperasionalisasikan rumus statistik korelasi produet moment tersebut diatas, data-data yang penulis peroleh di proses dengan mentabulasikan data ke dalam tabel. Hasil tabulasi data adalah sebagai berikut:

Tabel 4 : Seore Hasil Responden Tentang Prestasi Kerja Pegawai Pada Kantor Badan

\begin{tabular}{|c|c|c|c|c|c|c|}
\hline \multirow{2}{*}{$\begin{array}{c}\text { No. } \\
\text { Responden }\end{array}$} & \multicolumn{5}{|c|}{ Nomor Item } & \multirow{2}{*}{$\begin{array}{c}\text { Jumla } \\
\mathrm{h}\end{array}$} \\
\hline & 1 & 2 & 3 & 4 & 5 & \\
\hline 1 & 3 & 3 & 3 & 3 & 3 & 15 \\
\hline 2 & 3 & 3 & 3 & 3 & 3 & 15 \\
\hline 3 & 3 & 3 & 3 & 3 & 3 & 15 \\
\hline 4 & 3 & 3 & 3 & 3 & 3 & 15 \\
\hline 5 & 3 & 3 & 2 & 3 & 3 & 14 \\
\hline 6 & 3 & 3 & 3 & 3 & 3 & 14 \\
\hline 7 & 3 & 3 & 3 & 3 & 3 & 15 \\
\hline 8 & 3 & 2 & 3 & 3 & 3 & 14 \\
\hline 9 & 2 & 3 & 2 & 2 & 3 & 12 \\
\hline 10 & 3 & 3 & 3 & 3 & 3 & 15 \\
\hline 11 & 2 & 3 & 2 & 3 & 1 & 11 \\
\hline 12 & 3 & 3 & 3 & 3 & 3 & 15 \\
\hline 13 & 3 & 3 & 3 & 3 & 3 & 15 \\
\hline 14 & 2 & 2 & 2 & 2 & 2 & 10 \\
\hline 15 & 3 & 3 & 3 & 3 & 2 & 14 \\
\hline 16 & 3 & 3 & 3 & 2 & 3 & 14 \\
\hline 17 & 3 & 2 & 3 & 2 & 3 & 13 \\
\hline 18 & 2 & 2 & 3 & 3 & 3 & 13 \\
\hline 19 & 2 & 3 & 3 & 3 & 3 & 14 \\
\hline 20 & 3 & 2 & 3 & 3 & 3 & 14 \\
\hline 21 & 3 & 3 & 3 & 2 & 2 & 13 \\
\hline 22 & 2 & 2 & 1 & 3 & 2 & 10 \\
\hline 23 & 2 & 2 & 2 & 2 & 1 & 9 \\
\hline 24 & 3 & 3 & 3 & 3 & 3 & 15 \\
\hline 25 & 2 & 3 & 3 & 2 & 3 & 13 \\
\hline 26 & 3 & 2 & 2 & 2 & 3 & 12 \\
\hline
\end{tabular}
Pengawas Daerah Kabupaten Tulang Bawang.

(Variabel X) 


\begin{tabular}{|l|l|l|l|l|l|l|}
27 & 3 & 3 & 3 & 3 & 3 & 15 \\
\hline 28 & 2 & 2 & 3 & 3 & 3 & 13 \\
\hline 29 & 3 & 3 & 3 & 3 & 3 & 15 \\
\hline
\end{tabular}

Sumber : Penyebaran angket, 2008

Tabel 5 : Seore Hasil Responden Tentang Prestasi Kerja Pegawai Pada Kantor Badan Pengawas Daerah Kabupaten Tulang Bawang.

(Variabel Y)

\begin{tabular}{|c|c|c|c|c|c|c|}
\hline \multirow{2}{*}{$\begin{array}{c}\text { No } \\
\text { Responden }\end{array}$} & \multicolumn{5}{|c|}{ No. Item } & \multirow{2}{*}{$\begin{array}{c}\text { Jumla } \\
\mathrm{h}\end{array}$} \\
\hline & 1 & 2 & 3 & 4 & 5 & \\
\hline 1 & 3 & 3 & 3 & 3 & 3 & 15 \\
\hline 2 & 3 & 3 & 3 & 3 & 3 & 15 \\
\hline 3 & 3 & 3 & 3 & 3 & 3 & 15 \\
\hline 4 & 3 & 3 & 3 & 3 & 3 & 15 \\
\hline 5 & 3 & 3 & 2 & 3 & 3 & 14 \\
\hline 6 & 3 & 3 & 3 & 3 & 3 & 15 \\
\hline 7 & 3 & 3 & 3 & 3 & 3 & 15 \\
\hline 8 & 3 & 2 & 3 & 3 & 3 & 14 \\
\hline 9 & 3 & 3 & 2 & 2 & 3 & 13 \\
\hline 10 & 2 & 3 & 2 & 3 & 3 & 13 \\
\hline 11 & 3 & 3 & 3 & 3 & 3 & 15 \\
\hline 12 & 3 & 3 & 3 & 2 & 1 & 12 \\
\hline 13 & 3 & 3 & 3 & 3 & 3 & 15 \\
\hline 14 & 2 & 2 & 2 & 2 & 2 & 10 \\
\hline 15 & 3 & 3 & 2 & 3 & 3 & 14 \\
\hline 16 & 3 & 3 & 3 & 3 & 3 & 15 \\
\hline 17 & 3 & 2 & 3 & 3 & 3 & 14 \\
\hline 18 & 2 & 3 & 3 & 3 & 3 & 14 \\
\hline
\end{tabular}

\begin{tabular}{|c|c|c|c|c|c|c|}
\hline 19 & 3 & 2 & 3 & 2 & 2 & 12 \\
\hline 20 & 3 & 3 & 3 & 3 & 3 & 15 \\
\hline 21 & 3 & 3 & 3 & 3 & 3 & 15 \\
\hline 22 & 2 & 2 & 1 & 3 & 2 & 10 \\
\hline 23 & 2 & 2 & 2 & 2 & 1 & 9 \\
\hline 24 & 3 & 3 & 3 & 3 & 3 & 15 \\
\hline 25 & 2 & 3 & 3 & 3 & 3 & 14 \\
\hline 26 & 3 & 2 & 2 & 2 & 3 & 12 \\
\hline 27 & 2 & 3 & 3 & 3 & 3 & 14 \\
\hline 28 & 2 & 2 & 3 & 3 & 3 & 13 \\
\hline 29 & 3 & 3 & 3 & 3 & 3 & 15 \\
\hline
\end{tabular}

Sumber : Penyebaran angket, 2008

Tabel 6 : Tabel Kerja Korelansi Produet Moment

\begin{tabular}{|c|c|c|c|c|c|}
\hline No & $\mathrm{X}$ & $\mathrm{Y}$ & $\mathrm{X}^{2}$ & $\mathrm{Y}^{2}$ & $\mathrm{XY}$ \\
\hline 1 & 15 & 15 & 225 & 225 & 225 \\
\hline 2 & 15 & 15 & 225 & 225 & 225 \\
\hline 3 & 15 & 15 & 225 & 225 & 225 \\
\hline 4 & 15 & 15 & 225 & 225 & 225 \\
\hline 5 & 14 & 14 & 196 & 196 & 196 \\
\hline 6 & 15 & 15 & 225 & 225 & 225 \\
\hline 7 & 15 & 15 & 225 & 225 & 225 \\
\hline 8 & 14 & 14 & 196 & 196 & 196 \\
\hline 9 & 12 & 13 & 144 & 169 & 156 \\
\hline 10 & 15 & 13 & 225 & 169 & 195 \\
\hline 11 & 11 & 15 & 121 & 225 & 165 \\
\hline 12 & 15 & 12 & 225 & 144 & 180 \\
\hline 13 & 15 & 15 & 225 & 225 & 225 \\
\hline
\end{tabular}




\begin{tabular}{|c|c|c|c|c|c|}
\hline 14 & 10 & 10 & 100 & 100 & 100 \\
\hline 15 & 14 & 14 & 196 & 196 & 196 \\
\hline 16 & 14 & 15 & 196 & 225 & 210 \\
\hline 17 & 13 & 14 & 169 & 196 & 182 \\
\hline 18 & 13 & 14 & 169 & 196 & 182 \\
\hline 19 & 14 & 12 & 196 & 144 & 168 \\
\hline 20 & 14 & 15 & 196 & 225 & 210 \\
\hline 21 & 15 & 15 & 169 & 225 & 195 \\
\hline 22 & 10 & 10 & 100 & 100 & 100 \\
\hline 23 & 9 & 9 & 81 & 81 & 81 \\
\hline 24 & 15 & 15 & 225 & 225 & 225 \\
\hline 25 & 13 & 14 & 196 & 196 & 182 \\
\hline 26 & 12 & 12 & 144 & 144 & 144 \\
\hline 27 & 15 & 14 & 225 & 196 & 210 \\
\hline 28 & 13 & 13 & 169 & 169 & 169 \\
\hline 29 & 15 & 15 & 225 & 225 & 225 \\
\hline$\sum$ & 393 & 397 & 5411 & 5517 & 5442 \\
\hline
\end{tabular}

Sumber : Data diolah, 2008

Setelah dilakukan tabulasi data kedalam tabel, maka diketahui :

$\Sigma X=393$

$\Sigma \mathrm{Y}=397$

$\Sigma \mathrm{X}=5411$

$\Sigma \mathrm{Y}=5517$

$\Sigma \mathrm{XY}=5442$

$\mathrm{N}=29$

Data tersebut dimasukan ke dalam rumus, sebagai berikut:

$$
r x y=\frac{n \cdot \Sigma x y-(\Sigma x)(\Sigma y)}{\sqrt{ }\left[\Sigma x^{2}-(\Sigma x)^{2}\right]\left[n \Sigma y^{2}-(\Sigma y)^{2}\right]}
$$

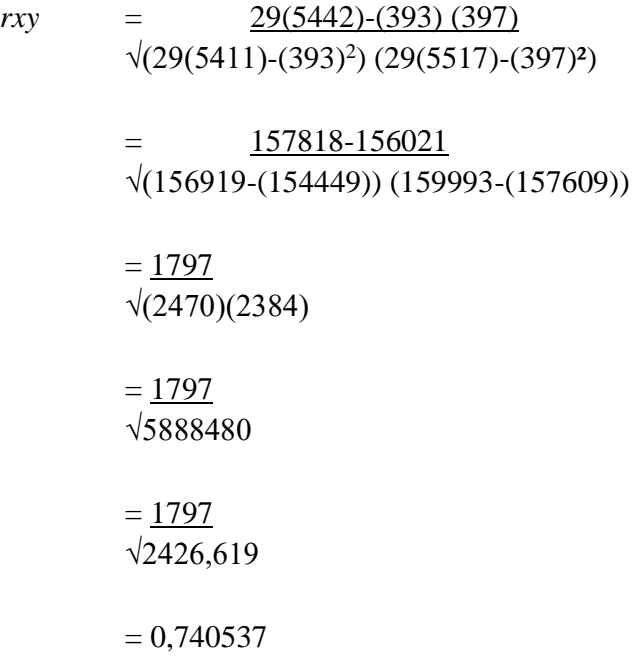

Dari perhitungan di atas, diketahui : $\mathrm{r}_{\text {hitung }}=$ 0,740. Hasil tersebut jika dikonsultasikan dengan nilai $\mathrm{r}_{\text {tabel }}$ dengan $\mathrm{N}=29$ pada taraf signifikansi $1 \%=0,470$ dan taraf signifikansi $5 \%=0,367$. Hasil konsultasi ternyata rhitung lebih besar daripada $r_{\text {tabel }}$. Dengan demikian hipotesis :

$\mathrm{H}_{0} \quad$ : Promosi jabatan tidak berpengaruh terhadap prestasi kerja pegawai padaKantor Badan Pengawas Daerah Kabupaten Tulang Bawang, Ditolak.

$\mathrm{H}_{1} \quad$ : Promosi jabatan berpengaruh terhadap prestasi kerja pegawai pada KantorBadan Pengawas Daerah Kabupaten Tulang Bawang, Diterima.

Untuk mengetahui tingkat ke-eratan pengaruh promosi jabatan terhadap prestasi kerja pegawai pada kantor Badan Pengawas Daerah Kabupaten Tulang Bawang, maka hasil perhitungan $\left(\mathrm{r}_{\text {hitung }}\right)=0,740$ akan dikonsultasikan dengan tabel nilai standar korelasi. Setelah dikonsultasikan ternyata nilai 0,740 termasuk dalam standar nilai antara 0,600-0,800 dengan kategori interprestasi "berpengaruh tinggi".

Setelah diketahui angka koefisien korelasi pada perhitungan sebelumnya, 
maka untuk mengetahui kadar prosentasi hubungan pemberian insentif terhadap motivasi kerja pegawai tersebut, penulis mempergunakan rumus koefisien penentu seperti telah disajikan pada bab sebelumnya:

$$
\begin{aligned}
\mathrm{Kp} & =\mathrm{r}^{2} \times 100 \% \\
& =(0,740)^{2} \times 100 \% \\
& =0,5476 \times 100 \% \\
& =54,76 \text { atau dibulatkan }-55 \% \\
& \text { Dari perhitungan diatas, dapat }
\end{aligned}
$$
disimpulkan bahwa promosi jabatan pada Kantor Badan Pengawas Daerah Kabupaten Tulang Bawang mempengaruhi prestasi kerja pegawai sebesar $55 \%$, sedangkan faktor-faktor lain yang mempengaruhi sebesar $45 \%$. Hal ini berarti bahwa apabila promosi jabatan dilaksanakan dengan baik atau tinggi, maka prestasi kerja pegawai akan meningkat yaitu pada derajat kebebasan 0,05.

\subsection{Analisis Kualitatif}

Setelah mengadakan pengumpulan data dari para responden penelitian yang berjumlah 29 orang pegawai Kantor Badan Pengawas Daerah Kabupaten Tulang Bawang, yaitu dengan berdasarkan pada hasil penyebaran angket, kemudian dapat disajikan data hasil penelitian sebagai berikut :

Dalam menganalisis data, akan dipergunakan analisis statistik yang kemudian dataYang dapat digolongkan/disajikan dalam bentuk tabel tunggal dan tabel silang, yaitu :

$$
\mathrm{I}=\underline{\mathrm{Nt}-\mathrm{Nr}}
$$

\section{K}

Keterangan :

I = Interval

$\mathrm{Nt} \quad=$ Nilai tertinggi
$\mathrm{Nr}=$ Nilai terendah

$\mathrm{K}=$ Kategori

(Sutrisno Hadi, 2000:19)

Adapun analisis tersebut, akan diuraikan pada penjelasan berikut ini:

\section{Analisis Tabel Tunggal}

\section{a. Promosi Pegawai}

Berdasarkan pada hasil angket tentang promosi jabatan yang dijalankan padaKantor Badan Pengawas Daerah Kabupaten Tulang Bawang, yaitu hasilnya dapat digolongkan:

a. Skor tertinggi adalah : 15

b. Skor terendah adalah : 9

$$
1=\underline{15-9}=2
$$$$
3
$$

Skor promosi jabatan tersebut, dibagi lagi menjadi tiga kategori dengan ketentuanSebagai berikut :

- Baik, Dengan Skor antara

$$
\text { : } 14-15
$$

- Eukup Baik, Dengan Skor antara : 12-13

- Kurang Baik, Dengan Skor antara :9-11

Untuk lebih jelasnya dapat dilihat pada tabel berikut:

Tabel : Tanggapan Responden Mengenai Promosi Jabatan

\begin{tabular}{|c|l|c|c|}
\hline NO. & Kategori & $\begin{array}{c}\text { Jumlah } \\
\text { Orang }\end{array}$ & $\begin{array}{c}\text { Prosentase } \\
\%\end{array}$ \\
\hline 1 & Baik & 18 & 62,07 \\
\hline 2 & $\begin{array}{l}\text { Eukup } \\
\text { baik }\end{array}$ & 7 & 24,14 \\
\hline 3 & $\begin{array}{l}\text { Kurang } \\
\text { baik }\end{array}$ & 4 & 13,79 \\
\hline & Jumlah & 29 & 100,00 \\
\hline
\end{tabular}

Sumber : Data diolah, 2008 
Berdasarkan data pada tabel di atas, didapatkan keadaan dari sejumlah 29 responden, 18 responden atau $(62,07 \%)$, menyatakan promosi jabatan dalam kategori baik, 7 responden atau $(24,14 \%)$ menyatakan sedang dan 4 responden atau $(13,79 \%)$ menyatakan rendah. Dari hasil tabel diatas, dapat disimpulkan bahwa promosi jabatan yang dilaksanakan pada Kantor Badan Pengawas Daerah Kabupaten Tulang Bawang adalah dalam kategori baik.

\section{b. Prestasi Kerja Pegawai}

Berdasarkan pada hasil angket tentang prestasi kerja pegawai, skornya dapat digolongkan sebagai berikut :

a. $\quad$ Skor tertinggi $=15$

b. Skor terendah $=9$

$$
I=\underline{15-93}=2
$$

Skor prestasi kerja pegawai ini dibagi menjadi tiga kategori dengan ketentuan sebagai berikut:

- Baik, dengan skor

$14-15$

- Eukup Baik, dengan skor $12-13$

- Kurang Baik, dengan skor : 9-11

Untuk mengetahui seeara lebih jelas dan terperinei mengenai prestasi kerja pegawai pada Kantor Badan Pengawas Daerah Kabupaten Tulang dapat di lihat pada tabel yang akan dikemukakan di bawah ini:

Tabel 8 : Tanggapan Responden Mengenai Prestasi Kerja Pegawai

\begin{tabular}{|c|l|c|c|}
\hline NO. & Kategori & $\begin{array}{c}\text { Jumlah } \\
\text { Orang }\end{array}$ & $\begin{array}{c}\text { Prosentase } \\
\text { \% }\end{array}$ \\
\hline 1 & Baik & 18 & 62,07 \\
\hline 2 & Eukup & 7 & 24,14 \\
\hline
\end{tabular}

\begin{tabular}{|c|l|c|c|}
\hline & baik & & 13,79 \\
\hline 3 & $\begin{array}{l}\text { Kurang } \\
\text { baik }\end{array}$ & 4 & 100,00 \\
\hline & Jumlah & 29 & .
\end{tabular}

Sumber : Data diolah, 2008

Berdasarkan data pada tabel di atas, didapatkan keadaan sejumlah 29 orang responden yang menyatakan prestasi kerja pegawai baik berjumlah 15 orang responden $(68,97 \%)$, yang menyatakan prestasi kerja pegawai eukup baik berjumlah 6 orang responden $(20,69 \%)$ dan yang menyatakan prestasi kerja pegawai kurang baik berjumlah 3 orang responden $(10,34 \%)$. Dengan demikian dari hasil tabel tersebut dapat disimpulkan bahwa prestasi kerja pegawai pada Kantor Badan pengawas Daerah Kabupaten Tulang Bawang adalah dalam kategori baik.

\section{Analisis Tabel Silang}

Untuk mengetahui bagaimana pengaruh promosi jabatan terhadap prestasi kerja pegawai pada Kantor Badan Pengawas Kabupaten Daerah Tulang Bawang dapat dilihat pada penjelasan tabel silang yang akan dikemukakan berikut ini:

Dari data pada tabel 9 diatas, dapat diuraikan sebagai berikut:

Tabel 9 : Pengaruh Promosi Jabatan Terhadap Prestasi Kerja Pegawai Pada Kantor BADAN Pengawas Daerah Kabupaten Tulang Bawang

\begin{tabular}{|c|c|c|c|c|c|}
\hline & & \multicolumn{4}{|c|}{ Prestasi kerja } \\
\hline & & Baik & $\begin{array}{c}\text { Eukup } \\
\text { Baik }\end{array}$ & $\begin{array}{c}\text { Kurang } \\
\text { Baik }\end{array}$ & Jumlah \\
\hline \multirow{2}{*}{ 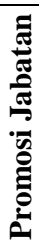 } & Baik & $\begin{array}{c}12 \\
42,81 \\
\%\end{array}$ & $\begin{array}{c}5 \\
16,65 \\
\%\end{array}$ & $\begin{array}{c}3 \\
9,51 \%\end{array}$ & $\begin{array}{c}20 \\
68,97 \\
\%\end{array}$ \\
\hline & $\begin{array}{l}\text { Eukup } \\
\text { baik }\end{array}$ & $\begin{array}{c}4 \\
12,84 \\
\%\end{array}$ & $\begin{array}{c}1 \\
4,99 \%\end{array}$ & $\begin{array}{c}1 \\
2,85 \%\end{array}$ & $\begin{array}{c}6 \\
20,69 \\
\%\end{array}$ \\
\hline
\end{tabular}




\begin{tabular}{|l|c|c|c|c|}
$\begin{array}{l}\text { Kurang } \\
\text { baik }\end{array}$ & $\begin{array}{c}2 \\
6,42 \%\end{array}$ & $\begin{array}{c}1 \\
2,50 \%\end{array}$ & $\begin{array}{c}0 \\
1,43 \%\end{array}$ & $\begin{array}{c}3 \\
10,34 \\
\%\end{array}$ \\
\hline & 18 & 7 & 4 & 29 \\
Jumlah & $\begin{array}{c}62,07 \\
\%\end{array}$ & $\begin{array}{c}24,14 \\
\%\end{array}$ & $13,79 \%$ & $\begin{array}{c}100,00 \\
\%\end{array}$ \\
\hline
\end{tabular}

Sumber : Data Diolah, 2008

Dari data tabel 9 diatas, dapat diuraikan sebagai berikut :

1. Dari 18 responden yang menyatakan promosi jabatan baik 12 responden menyatakan prestasi kerja pegawai juga baik, 4 responden menyatakan eukup baik dan 2 responden menyatakan kurang baik. Begitu juga sebaliknya dari 20 responden yang menyatakan prestasi kerja pegawai baik 12 diantaranya menyatakan promosi jabatan baik, 5 responden menyatakan eukup baik dan 3 responden menyatakan kurang baik.

2. Dari 7 responden yang menyatakan promosi jabatan eukup baik 5 diantaranya menyatakan prestasi kerja pegawai baik sedangkan yang menyatakan eukup baik dan kurang baik masing-masing 1 responden. Begitu juga sebaliknya dari 6 responden yang menyatakan prestasi kerja pegawai eukup baik, 4 responden diantaranya menyatakan promosi jabatan baik, sedangkan yang menyatakan eukup baik dan kurang baik sebanyak 1 responden.

3. Dari 4 responden yang menyatakan promosi jabatan kurang baik, 3 responden menyatakan prestasi kerja baik, 1 responden menyatakan eukup baik dan tidak ada responden yang menyatakan prestasi kerja pegawai kurang baik. Begitu juga sebaliknya dari 3 responden yang menyatakan prestasi kerja pegawai kurang baik, 2 responden menyatakan promosi jabatan baik, 1 responden menyatakan eukup baik dan tidak ada responden yang menyatakan kurang baik.

Berdasarkan hasil tabel tersebut diatas, maka dapat disimpulkan bahwa jika pelaksanaan promosi jabatan dijalankan dengan baik, maka akan meningkatkan prestasi kerja pegawai, hal ini tampak terlihat atau terbukti dari hasil analisis tabel silang tersebut bahwa pelaksanaan promosi jabatan yang baik akan diikuti oleh peningkatan prestasi kerja pegawai, demikian pula sebaliknya jika prestasi kerja kurang baik dan atau tidak baik, maka pelaksanaan promosi jabatan juga kurang atau tidak terlaksana dengan baik.

\section{KESIMPULAN DAN SARAN}

\subsection{Kesimpulan}

Berdasarkan hasil penelitian dan hasil pembahasan yang telah penulis lakukan, maka penulis dapat menarik kesimpulan sebagai berikut:

1. Dalam melaksanakan kebijakan promosi jabatan pada Kantor Badan Pengawas Daerah Kabupaten Tulang Bawang, dilakukan berdasarkan azas senioritas, kemampuan dan perpaduan keduanya (gabungan senioritas dan kemampuan).

2. Dari hasil perhitungan dengan menggunakan uji statistik korelasi produet moment, diketahui: Thitung 0,740. Hasil tersebut jika dikonsultasikan dengan nilai Ttabel dengan $\mathrm{N}=29$ pada taraf signifikansi $1 \%=0,470$ dan taraf signifikansi $5 \%$ $=0,367$. Hasil konsultasi ternyata Thing lebih besar daripada bel. Dengan demikian hipotesis yang penulis ajukan bahwa promosi jabatan berpengaruh terhadap 
peningkatan prestasi kerja pegawai, Diterima.

3. Setelah dikonsultasikan dengan tabel nilai standar korelasi, diketahui bahwa $r$ hitung 0,740 termasuk dalam kategori interprestasi berpengaruh tinggi. Sedangkan hasil perhitungan koefisien penentu adalah 55\% yang berarti bahwa promosi jabatan berpengaruh terhadap prestasi kerja pegawai sebanyak $55 \%$ sedangkan sisanya $45 \%$ dipengaruhi faktorfaktor lain.

4. Hasil analisis dengan menggunakan tabel tunggal maupun tabel silang diketahui bahwa apabila pelaksanaan promosi jabatan baik akan mempengaruhi prestasi kerja pegawai menjadi baik. Demikian pula sebaliknya apabila prestasi kerja pegawai kurang atau tidak baik maka pelaksanaan promosi jabatan juga menjadi kurang atau tidak baik.

\subsection{Saran-Saran}

Berdasarkan pembahasan dan kesimpulan di atas, maka penulis menyarankan halhalSebagai berikut :

1. Dalam pelaksanaan promosi jabatan hendaknya dilaksanakan sesuai ketentuan dengan memperhatikan syarat-syarat, prosedur, kemampuan dan keterampilan, serta mempertimbangkan faktor pengetahuan dan pengalaman. Hal ini dimaksudkan agar penempatan kekosongan jabatan akan terlaksana sesuai dengan kebutuhan dan berjalan tanpa hambatan.

2. Prestasi kerja pegawai yang telah baik tetap dipertahankan dan lebih ditingkatkan agar dapat mempengaruhi prestasi kerja pegawai yang kurang baik menjadi lebih baik, sehingga pada saat promosi jabatan akan dilaksanakan telah tersedia pegawai yang siap dipromosikan dan memungkinkan akan menimbulkan persaingan yang sehat.

3. Tindakan pendisiplinan dan pengawasan perlu lebih diperketat, baik mengenai waktu, kebijaksanaan maupun seleksi.

\section{DAFTAR PUSTAKA}

Arikunto, Suharsimi., 2004, Prosedur Penelitian, Edisi Revisi,

PT. Bina Aksara,Jakarta.

Dharma, Agus, SH., 1989, Manajement Personalia, Ghalia

Indonesia, Jakarta.

Hadi, Sutrisno., 1995, Metode Reseaeh, Yayasan Fakultas

UGM Psykologi UGM.Yogyakarta

Hari, Purwono., 1983, Tata Personalia, Eroseo, Bandung.

Koentjorodiningrat., 1987, Metode Penelitian Masyarakat,

Ghalia Indonesia. Jakarta.

Manullang, Drs., 1991, Manajement Personalia, Alfabeta,

Bandung

Malayu SP. Hasibuan, 2005, Manajemen: Dasar, Pengertian

dan Masalah, Bumi Aksara, Jakarta

Moekijat, Drs., 1997, Manajement Kepegawaian, Mandar

Maju, Bandung.

Moenir, AS, 1995, Pendekatan Manusiawi dan Organisasi 
Terhadap PembinaanPegawai, Gunung Agung, Jakarta.

Ranupandoyo, Heidjraehman, Drs., 1992, Manajemet

Personalia, Fakultas Ekonomi UGM Yogyakarta.

Siagian, SP, Dr. MPA, 2001, Organisasi Kepemimpinan dan

Prilaku Adminstrasi,PT. Bina Aksara, Jakarta.

Winarso, Suraehman., 1989, Tehnik dan Dasar Reseaeh,

Tarsito, Bandung.

Sutarso, Drs., 1987, Dasar-dasar Organisasi, UGM,

Yogyakarta

Pane, Thamrin, Drs., 1976, Adminstrasi Negara, Jakarta

Winardi, Drs., 1990, Personal Manajement, Bandung. 